\title{
Carbohydrate Metabolism in Pregnancy
}

\author{
VIII. METABOLISM OF ADIPOSE TISSUE ISOLATED \\ FROM FED AND FASTED PREGNANT RATS \\ DURING LATE GESTATION
}

\author{
Robert H. Knopp, Emilio Herrera, and Norbert Freinkel \\ From the Section of Endocrinology and Metabolism, Departments of Medicine \\ and Biochemistry, Northwestern University Medical School, \\ Chicago, Illinois 60611
}

\begin{abstract}
A в S T R A C T The effects of late pregnancy on adipose tissue metabolism have been examined in fed and fasted rats. Lumbar fat was excised from 19-day pregnant and age-matched virgin rats which had been given unrestricted access to food ("fed") or fasted for $48 \mathrm{hr}$ before sacrifice.

In the fed state, adipose tissue from pregnant rats displayed an increased content of free fatty acids (FFA). This coincided with augmented cleavage of preformed glycerides during incubation in vitro as evidenced by greater net production of FFA and glycerol, and altered disposition of labeled glucose. The enhanced lipolysis was independent of the availability of glucose and was not accompanied by impaired responsiveness to the antilipolytic or to the lipogenic actions of added insulin. In the presence of glucose and albumin, esterification as well as lipolysis was greater in adipose tissue from pregnant than nongravid animals. All the differences were exaggerated by prior fasting.
\end{abstract}

These properties of adipose tissue during late gestation have been ascribed to a primary activation of lipolysis rather than impaired esterification or resistance to insulin. It has been suggested that the hormones of pregnancy may be responsible. Although increased intake of food and heightened availability of insulin may

Part of this work. was presented at the 51st Annual Meeting of the Endocrine Society, New York, 27-29 June 1969 (Abstract No. 6).

Dr. Knopp is a U. S. Public Health Service Trainee in Endocrinology and Metabolism, 1966-1968. His present address is U. S. Public Health Service, Diabetes and Arthritis Section, Boston, Mass. Dr. Herrera is a Research Fellow in Endocrinology and Metabolism, 1965-1968. His present address is Consejo Superior de Investigaciones Cientificas, Instituto “G. Marañon,” Velazquez 144, Madrid 6, Spain. offset the net lipolytic effects in the fed state, a heightened turnover of adipose stores is always present. Thus, the pregnant animal appears better poised to mobilize preformed fat whenever exogenous nutrients are withheld.

\section{INTRODUCTION}

Accelerated mobilization of depot fat in response to fasting has long been recognized as one of the metabolic characteristics of late pregnancy (1). Recent findings suggest that turnover in adipose depots may be altered in the fed state as well. Thus, plasma free fatty acids (FFA) are increased during late gestation in the rat even when access to food is uninterrupted (2-5). These observations, and the paucity of published data concerning adipose tissue in pregnancy, prompted the present studies. Incubations were performed in vitro with lumbar fat from fed and fasted 19-day pregnant, and age-matched nongravid rats. Segments of adipose tissue rather than isolated cells were employed in order to minimize preparative delay, and to preserve the intracellular allosteric and hormonal interrelationships that might be of regulatory significance in vivo.

\section{METHODS}

Pregnant primipara and age-matched virgin female rats were secured from Charles River Laboratories, Wilmington, Mass., and housed as in previous studies $(5,6)$. Experiments were conducted on day 19 of pregnancy (age 60-70 days; fetal weights $1.5-2.0 \mathrm{~g}$ ). Animals had been given continuing access to Purina Chow pellets ("fed") or deprived of all food but not drinking water for the preceding $48 \mathrm{hr}$ ("fasted"). Rats were maintained in dark animal quarters from 6 p.m. to 8 a.m. each day and sacrificed before 11 a.m. Pregnant animals with litters of less than eight fetuses were excluded.

Right and left lumbar fat pads were excised, and two

1438 The Journal of Clinical Investigation Volume 491970 
70-80 mg pieces, one from each side, were introduced into $20-\mathrm{ml}$ vials containing $2 \mathrm{ml}$ of either one of the following incubation media: (a) KRB: modified Krebs-Ringer-bicarbonate containing gelatin $(<2 \mathrm{mg} / \mathrm{ml})$ as per Ball, Martin, and Cooper (7) to prevent absorption of insulin to glassware, or (b) KRB-Alb: modified Krebs-Ringer-Bicarbonate containing approximately $0.4 \mathrm{~mm}$ (i.e. $28 \mathrm{mg} / \mathrm{ml}$ ) albumin (Armour: Bovine albumin) which had been treated with charcoal adsorption (8) and extensive dialysis in this laboratory to remove free fatty acids (FFA) and organic acids. Heptane extracts of $10-\mathrm{mg}$ aliquots of such treated albumin contained an average of $0.030 \mu$ moles titratable acid. Insulin and glucose were addèd to KRB or KRBAlb as described in the text. The insulin contained "less than $0.005 \%$ glucagon" and was generously supplied by Dr. Mary Root of Eli Lilly \& Co. Epinephrine was prepared according to Hagen and Ball (9), diluted 1000-fold in KRB immediately before use, and added to a final concentration of $0.1 \mu \mathrm{g} / \mathrm{ml}$. Preparations of glucose labeled in carbon-1 or -6 (glucose-1-14 $\mathrm{C}$; glucose-6- ${ }^{14} \mathrm{C}$ ) were purchased from New England Nuclear Co.; 0.5 or $1.0 \mu \mathrm{Ci}$ was added to individual vessels, the larger amounts being used with tissues from fasted rats.

Vessels were sealed with rubber caps, gassed with $95 \%$ $\mathrm{O}_{2}-5 \% \mathrm{CO}_{2}$, and incubated at $38^{\circ} \mathrm{C}$ in a Dubnoff shaker as described previously $(10,11)$. For experiments with labeled glucose, ${ }^{14} \mathrm{CO}_{2}$ was collected as before (11) ; total lipids were extracted by the method of Folch, Lees, and SloaneStanley (12) and washed twice with saline. Lipid extracts were saponified $\left(1 \mathrm{hr} ; 80^{\circ} \mathrm{C} ; 5 \mathrm{~N}\right.$ methanolic $\left.\mathrm{KOH}\right)$ and the radioactivity was partitioned into fatty acids and glyceride-glycerol (13). Radioactive standards were prepared from vessels which had been incubated without tissues.

Glycerol concentrations in tissues and media were measured enzymatically (14) ; recovery of glycerol added to tissue extracts exceeded $90 \%$. FFA were extracted from tissue and media as per Dole and Meinertz (15); the heptane extracts were reduced to dryness under $\mathrm{N}_{2}$ and resuspended in chloroform. Activated silicic acid was added to the chloroform to remove phospholipids as described elsewhere (5), and FFA were estimated by the Duncombe procedure (16). The residual pellet after. lipid extraction of tissues was employed to estimate total tissue protein by the procedure of Lowry, Rosebrough, Farr, and Randall (17) and DNA-phosphorus by the method of Schmidt and Thannhauser (18). Tissue protein was employed as a reasonable index of functional adipocyte mass (19) and all measurements were expressed per milligram tissue protein. ${ }^{1}$

\footnotetext{
${ }^{1}$ Wet weights of lumbar fat pads were about $50 \%$ greater in fed 19-day pregnant than in age-matched virgin rats. Total DNA-phosphorus within fat pads was not significantly different $(17.9 \pm 2.5$ vs. $17.1 \pm 1.6 \mu \mathrm{g}$ DNA-phosphorus per fat pad from pregnant and virgin animals respectively) whereas glycerides were more abundant in the pregnant $(223.2 \pm 6.6$ vs. $153.0 \pm 3.0 \mu$ moles esterified fatty acids per $\mu \mathrm{g}$ DNA-phosphorus; $P<0.001)$. Thus, much of the difference in weight appears to be due to the amount of fat per cell rather than the number of fat cells per fat pad. In keeping with this conclusion, we encountered substantially lower concentrations of protein (i.e. $\mathrm{mg}$ protein/g wet weight) in the lumbar adipose tissue from fed pregnant animals (11.9 \pm 0.1 vs. $17.4 \pm 0.1 ; P<0.001)$. Relative differences in protein concentrations were even greater after $48 \mathrm{hr}$ fast (i.e. $12.3 \pm 0.1$ vs. $27.0 \pm 3.2 \mathrm{mg}$ protein $/ \mathrm{g}$ lumbar adipose tissue in pregnant vs. virgin respectively; $P<0.001)$. However, the heightened vascularity and proportionately greater con-
}

For statistical analyses, unpaired data were compared using the student $t$ test. Paired data were evaluated for statistical significance by assessing whether the ratios of "experimental" to "control" values deviated significantly from unity. Student $t$ tests were performed after logarithmic transformation of the ratios (21).

\section{RESULTS}

\section{Adipose tissue from fed animals}

\section{ReLATIONSHips In Vivo}

Elsewhere $(4,5)$, we have confirmed that plasma glucose and ketones are lower $(3,22)$, whereas FFA are higher $(2,3)$ in fed 19-day pregnant than in age-matched virgin rats. We have also reported that plasma immunoreactive insulin is almost doubled in fed gravid vs. virgin animals $(4,5)$. To assess whether the elevations of plasma FFA truly coincide with an increased availability of FFA from adipose tissue stores, portions of lumbar fat from animals given continuing access to food were excised rapidly, frozen in liquid $\mathrm{N}_{2}$, and analyzed for glycerol and FFA. As shown in Table I, the' tissue content of FFA was substantially greater in fat from fed pregnant than virgin rats $(P<0.02) .^{2}$ Values for tissue glycerol were low and not significantly different in tissues from pregnant and virgin animals (Table I).

\section{Metabolism In Vitro}

The augmented tissue FFA of the pregnant (as cf. virgin) rats in the fed state could result from: $(a)$ a primary defect in esterification due directly to the lower plasma glucose, or indirectly to diminished effectiveness of insulin upon glucose utilization; or (b) a primary increase in lipolysis due directly to increased availability of a lipolytic agent, or indirectly to diminished effectiveness of insulin upon restraining triglyceride lipase; or (c) "carry-over" into fed state of the "accelerated starvation" (1) that could occur between feedings during

tributions from occluded blood (20) may render protein concentration a less reliable index of the functional mass of the fat cells within adipose tissue after fasting.

"Ballard and Hanson have estimated "glucose space" in epididymal fat from fed and $72 \mathrm{hr}$ fasted rats, and employed those measurements, and concurrent analyses of plasma to correct for extracellular contributions to the apparent concentrations of metabolites in adipose tissue in vivo (20). The tissue concentrations of FFA shown in Table I suffciently exceeded those of plasma FFA that they were not altered meaningfully when corrected on the basis of the average reported "glucose spaces" (20) (i.e., $4.90 \%$ and $7.42 \%$ of total adipose tissue space in fed and fasted animals respectively) and the average plasma FFA which we have observed in fed and $48 \mathrm{hr}$ fasted virgin and 19-day pregnant rats (5). Corrected mean \pm SEM values for adipose tissue content of FFA ( $\mu$ moles/mg tissue protein) in pregnant vs. virgin rats were: $0.269 \pm 0.040$ vs. $0.154 \pm 0.024(P<0.05)$ in fed and $0.600 \pm 0.038$ vs. $0.238 \pm 0.015(P<0.001)$ in fasted animals respectively. 
TABLE I

Effect of Pregnancy on Adipose Tissue Content of FFA and Glycerol*

\begin{tabular}{ll}
\hline FFA & Glycerol \\
\hline umoles/mg tissue protein
\end{tabular}

A. Fed rats

\begin{tabular}{|c|c|c|}
\hline Pregnant & $0.258 \pm 0.038(6)$ & $0.012 \pm 0.001$ \\
\hline Virgin & $0.147 \pm 0.023$ & $0.011 \pm 0.002$ \\
\hline$P$ & $<0.02$ & NS \\
\hline
\end{tabular}

B. Fasted rats

\begin{tabular}{ccc} 
Pregnant & $0.560 \pm 0.036(12)$ & $0.036 \pm 0.005(8)$ \\
Virgin & $0.222 \pm 0.014(8)$ & $0.020 \pm 0.002(12)$ \\
$P$ & $<0.001$ & $<0.01$ \\
\hline
\end{tabular}

* Segments of lumbar fat were rapidly excised from 19-day pregnant and age-matched virgin rats which had been given uninterrupted access to food ("fed") or deprived of food for $48 \mathrm{hr}$ ("fasted") prior to sacrifice. Mean ISEM values are listed above; ( ) denotes number of animals; $P$ indicates significance of differences between values in pregnant and virgin rats; $\mathrm{NS}=$ not significant.

late gestation. To distinguish among these possibilities, segments of lumbar fat from fed pregnant and virgin rats were incubated under conditions which eliminated the differences in the concentration of plasma glucose to which they are exposed in vivo.

Oxidation and esterification of labeled glucose. During incubation for $60 \mathrm{~min}$ in $\mathrm{KRB}$ containing $5 \mathrm{mM}$ glucose labeled in carbon- 1 or -6 , oxidation of carbon- 6 was greater by adipose tissue from fed pregnant than fed virgin rats $(P<0.02)$, and more labeled glycerideglycerol was formed from both carbon-1 $(P<0.05)$ and carbon-6 $(P<0.05)$ (Table II).

With epididymal fat, analogous patterns have been elicited by the addition of lipolytic agents in vitro (10, 23-27). Thus, the increases in carbon- 6 oxidation and glyceride-glycerol formation could be compatible with antecedent activation of lipolysis in vivo. However, since such changes in glucose metabolism have also been effected by simply increasing tissue FFA $(10,23,25)$, the phenomena might merely reflect the higher initial intracellular FFA (Table I). Accordingly, more direct assessments of fat turnover were secured during longer incubations, in the presence of albumin as an extracellular FFA-acceptor.

Net release of FFA and glycerol in albumin-containing systems. Mean $\pm_{\mathrm{SEM}}$ values for FFA and glycerol following incubation for $150 \mathrm{~min}$ are summarized in Table III. ${ }^{\mathbf{s}}$

In KRB-Alb, adipose tissue from fed pregnant rats

${ }^{3}$ The Table depicts final values for the FFA within tissues, and the FFA and glycerol within media. Final concentrations of tissue glycerol were estimated in separate experiments. During $150 \mathrm{~min}$ incubation, tissue glycerol invariably declined below initial levels (Table I) and did not correlate with the net release of glycerol into the incubation media. Therefore, for economy of space, final tissue glycerol has been omitted from Tables III, IV, and VI although the values were employed to calculate "net lipolysis" and "net esterification" (vide supra).

TABLE II

Effects of Pregnancy on Oxidation and Esterification of Labeled Glucose by Adipose Tissue In Vitro*

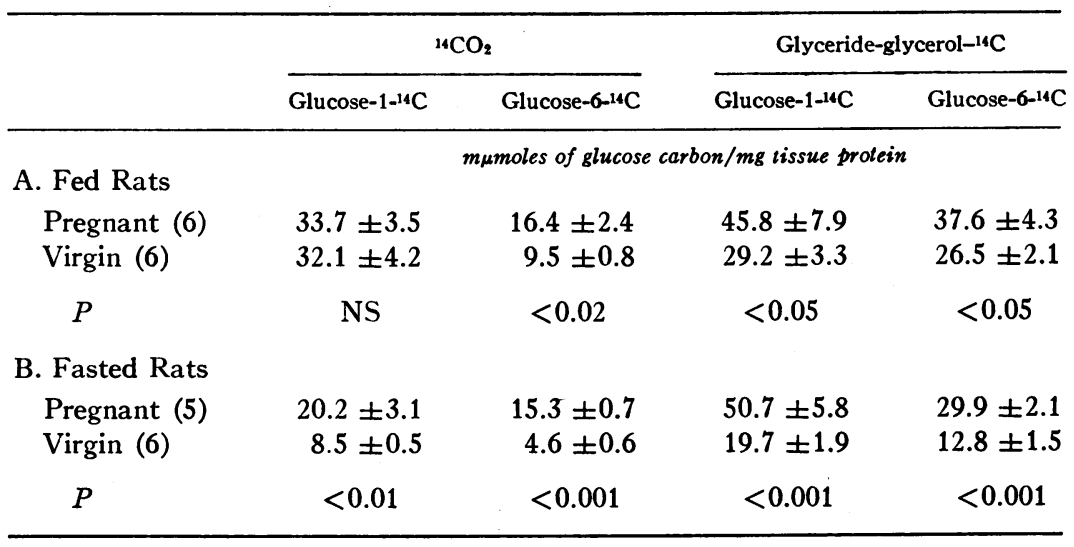

* Tissues were incubated $60 \mathrm{~min}$ in $2 \mathrm{ml} \mathrm{KRB}$ containing $5 \mathrm{~mm}$ glucose-1-14 $\mathrm{C}$ or glucose-6-14 C. Mean \pm SEM values for the evolution of ${ }^{14} \mathrm{CO}_{2}$ and formation of glyceride-glycerol-14 $\mathrm{C}$ have been expressed on the basis of $\mathrm{m} \mu$ moles of glucose carbon. ( ) denotes the number of animals in each category: $P$ indicates significance of differences between values for tissues from pregnant and virgin rats. 
TABLE III

Effects of Pregnancy on Lipolysis and Esterification by Adipose Tissue during Incubation in Albumin-Containing Media: Fed Rats*

\begin{tabular}{|c|c|c|c|c|c|}
\hline & KRB-Alb & $\begin{array}{l}\text { KRB-Alb } \\
\text { +glucose }\end{array}$ & $P \ddagger$ & $\begin{array}{c}\text { KRB-Alb + glucose } \\
+ \text { insulin }\end{array}$ & $P \ddagger$ \\
\hline $\begin{array}{l}\text { Final medium } \\
\text { glycerol }\end{array}$ & \multicolumn{3}{|c|}{ 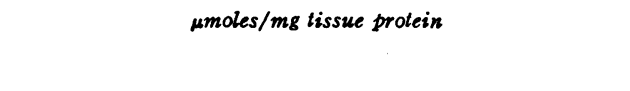 } & \multicolumn{2}{|c|}{ $\mu m o l e s / m g$ lissue prolein } \\
\hline $\begin{array}{l}\text { Pregnant } \\
\text { Virgin } \\
\quad P \S\end{array}$ & $\begin{array}{c}0.151 \pm 0.019 \\
0.094 \pm 0.008 \\
<0.02\end{array}$ & $\begin{array}{c}0.217 \pm 0.019 \\
0.148 \pm 0.010 \\
<0.01\end{array}$ & $\begin{array}{l}<0.01 \\
<0.01\end{array}$ & $\begin{array}{c}0.134 \pm 0.015 \\
0.089 \pm 0.013 \\
<0.05\end{array}$ & $\begin{array}{l}<0.001 \\
<0.001\end{array}$ \\
\hline \multicolumn{6}{|c|}{ Final medium FFA } \\
\hline $\begin{array}{l}\text { Pregnant } \\
\text { Virgin } \\
\quad P\end{array}$ & $\begin{array}{c}0.235 \pm 0.019 \\
0.124 \pm 0.019 \\
<0.01\end{array}$ & $\begin{array}{c}0.167 \pm 0.029 \\
0.092 \pm 0.022 \\
<0.05\end{array}$ & $\begin{array}{c}<0.01 \\
\text { NS }\end{array}$ & $\begin{array}{c}0.035 \pm 0.022 \\
0.022 \pm 0.015 \\
\text { NS }\end{array}$ & $\begin{array}{l}<0.001 \\
<0.001\end{array}$ \\
\hline \multicolumn{6}{|c|}{ Final tissue FFA } \\
\hline $\begin{array}{l}\text { Pregnant } \\
\text { Virgin } \\
\quad P\end{array}$ & $\begin{array}{c}0.218 \pm 0.020 \\
0.127 \pm 0.007 \\
<0.01\end{array}$ & $\begin{array}{c}0.175 \pm 0.031 \\
0.118 \pm 0.010 \\
\text { NS }\end{array}$ & $\begin{array}{c}<0.01 \\
\text { NS }\end{array}$ & $\begin{array}{c}0.152 \pm 0.018 \\
0.092 \pm 0.013 \\
<0.02\end{array}$ & $\begin{array}{c}\text { NS } \\
<0.05\end{array}$ \\
\hline \multicolumn{6}{|l|}{ Net lipolysis } \\
\hline $\begin{array}{l}\text { Pregnant } \\
\text { Virgin } \\
\quad P\end{array}$ & $\begin{array}{c}0.435 \pm 0.056 \\
0.263 \pm 0.026 \\
<0.02\end{array}$ & $\begin{array}{c}0.663 \pm 0.054 \\
0.416 \pm 0.029 \\
<0.01\end{array}$ & $\begin{array}{l}<0.001 \\
<0.01\end{array}$ & $\begin{array}{c}0.398 \pm 0.043 \\
0.250 \pm 0.041 \\
<0.05\end{array}$ & $\begin{array}{l}<0.001 \\
<0.001\end{array}$ \\
\hline \multicolumn{6}{|c|}{ Net esterification } \\
\hline $\begin{array}{l}\text { Pregnant } \\
\text { Virgin } \\
\quad P\end{array}$ & $\begin{array}{c}0.206 \pm 0.039 \\
0.148 \pm 0.024 \\
\text { NS }\end{array}$ & $\begin{array}{c}0.545 \pm 0.045 \\
0.342 \pm 0.029 \\
<0.01\end{array}$ & $\begin{array}{l}<0.001 \\
<0.01\end{array}$ & $\begin{array}{c}0.435 \pm 0.066 \\
0.272 \pm 0.027 \\
<0.05\end{array}$ & $\begin{array}{l}<0.05 \\
<0.05\end{array}$ \\
\hline
\end{tabular}

* Tissues from fed 19-day pregnant $(n=6)$ and age-matched virgin $(n=6)$ rats were incubated 150 min in KRB containing approximately $0.4 \mathrm{mM}$ albumin (KRB-Alb). Effects of including $3.75 \mathrm{~mm}$ glucose (KRB-Alb + glucose) or $3.75 \mathrm{~mm}$ glucose plus $50 \mu \mathrm{U} / \mathrm{ml}$ insulin (KRB-Alb + glucose + insulin) in the incubation medium were evaluated. The table summarizes mean \pm SEM values for FFA within tissue and for FFA and glycerol within medium at the end of incubation in terms of $\mu$ moles $/ \mathrm{mg}$ tissue protein. Mean 土SEM values for net lipolysis and esterification ( $\mu$ molesFFA $/ \mathrm{mg}$ tissue protein) during incubation were derived as per Vaughan (28).

$\ddagger P$ denotes significance of the effects of glucose (i.e. KRB-Alb vs. KRB-Alb + glucose) or insulin (i.e. KRB-Alb + glucose vs. KRB-Alb + glucose + insulin) within each group of animals.

$\S P$ denotes significance of the effects of pregnancy by comparing pregnant vs. virgin animals.

released considerably more FFA than did tissue from fed virgin rats $(P<0.01)$. Tissue FFA at the end of incubation (Table III) persisted near levels found initially (Table I) so that the efflux represented greater generation of FFA rather than simple depletion of more abundant tissue stores. Indeed, derived values for the net production of FFA in KRB-Alb (i.e. final FFA [medium + tissue] - initial tissue FFA) were $0.229 \pm 0.038$ vs. $0.115 \pm 0.026 \mu$ moles $/ \mathrm{mg}$ protein for the tissues from pregnant vs. virgin animals respectively $(P<0.05)$.

Inclusion of $3.75 \mathrm{mM}$ glucose (i.e. KRB-Alb + glucose; Table III) obtunded the net release of FFA. However, as evidenced by the greater release of glycerol $(P<0.01)$, the tissues from gravid animals continued to cleave more glycerides.
The measurements of glycerol and FFA were combined to derive estimates of lipolysis and esterification as per Vaughan (28) (Table III). It was felt that the limited glycerokinase activity in white adiopse tissue (29), and the more recent direct documentation that glycerol is reutilized by epididymal fat in vitro," would not preclude application of the Vaughan calculations (28) to assess net changes during the period of incubation (30), and to compare pregnant vs. nongravid animals thereby. As estimated in this fashion $(28,30)$, net lipolysis during incubation in KRB-Alb was about $60 \%$ greater in tissues from pregnant animals $(P<$

'Herrera, E., A. Ayanz, and L. Lamas. 1968-1969. Unpublished observations. 
TABLE IV

Effects of Pregnancy on the Responsiveness of Adipose Tissue to Inhibition of Lipolysis by Insulin*

\begin{tabular}{|c|c|c|c|c|c|c|}
\hline & KRB & $\mathrm{KRB}+$ insulin & $P \ddagger$ & $\begin{array}{c}\text { KRB } \\
+ \text { epinephrine }\end{array}$ & $\begin{array}{c}\text { KRB + epinephrine } \\
\text { + insulin }\end{array}$ & $P_{+}^{+}$ \\
\hline $\begin{array}{l}\text { Final medium } \\
\text { glycerol }\end{array}$ & \multicolumn{3}{|c|}{ umoles/mg tissue protein } & \multicolumn{3}{|c|}{ $\mu$ moles $/ m g$ lissue protein } \\
\hline $\begin{array}{l}\text { Pregnant } \\
\text { Virgin } \\
\quad P \S\end{array}$ & $\begin{array}{c}0.079 \pm 0.013 \\
0.076 \pm 0.006 \\
\text { NS }\end{array}$ & $\begin{array}{c}0.063 \pm 0.008 \\
0.063 \pm 0.005 \\
\mathrm{NS}\end{array}$ & $\begin{array}{l}<0.01 \\
<0.001\end{array}$ & $\begin{array}{c}0.161 \pm 0.019 \\
0.152 \pm 0.015 \\
\text { NS }\end{array}$ & $\begin{array}{c}0.107 \pm 0.020 \\
0.109 \pm 0.018 \\
\text { NS }\end{array}$ & $\begin{array}{l}<0.01 \\
<0.01\end{array}$ \\
\hline \multicolumn{7}{|c|}{ Final tissue FFA } \\
\hline $\begin{array}{l}\text { Pregnant } \\
\text { Virgin } \\
\quad P\end{array}$ & $\begin{array}{c}0.327 \pm 0.050 \\
0.192 \pm 0.021 \\
<0.05\end{array}$ & $\begin{array}{c}0.305 \pm 0.045 \\
0.155 \pm 0.011 \\
<0.01\end{array}$ & $\begin{array}{c}\text { NS } \\
<0.02\end{array}$ & $\begin{array}{c}0.581 \pm 0.065 \\
0.404 \pm 0.045 \\
<0.05\end{array}$ & $\begin{array}{c}0.416 \pm 0.065 \\
0.236 \pm 0.046 \\
<0.05\end{array}$ & $\begin{array}{l}<0.001 \\
<0.001\end{array}$ \\
\hline \multicolumn{7}{|l|}{ Net lipolysis } \\
\hline $\begin{array}{l}\text { Pregnant } \\
\text { Virgin } \\
\quad P\end{array}$ & $\begin{array}{c}0.209 \pm 0.037 \\
0.200 \pm 0.018 \\
\text { NS }\end{array}$ & $\begin{array}{c}0.164 \pm 0.026 \\
0.160 \pm 0.016 \\
\text { NS }\end{array}$ & $\begin{array}{l}<0.01 \\
<0.001\end{array}$ & $\begin{array}{c}0.456 \pm 0.059 \\
0.428 \pm 0.045 \\
\mathrm{NS}\end{array}$ & $\begin{array}{c}0.300 \pm 0.062 \\
0.298 \pm 0.048 \\
\text { NS }\end{array}$ & $\begin{array}{l}<0.01 \\
<0.001\end{array}$ \\
\hline \multicolumn{7}{|c|}{ Net esterification } \\
\hline $\begin{array}{l}\text { Pregnant } \\
\text { Virgin } \\
\quad P\end{array}$ & $\begin{array}{c}0.131 \pm 0.021 \\
0.157 \pm 0.024 \\
\text { NS }\end{array}$ & $\begin{array}{c}0.136 \pm 0.018 \\
0.151 \pm 0.030 \\
\text { NS }\end{array}$ & $\begin{array}{l}\text { NS } \\
\text { NS }\end{array}$ & $\begin{array}{c}0.118 \pm 0.021 \\
0.172 \pm 0.024 \\
N S\end{array}$ & $\begin{array}{c}0.142 \pm 0.026 \\
0.176 \pm 0.027 \\
\text { NS }\end{array}$ & $\begin{array}{l}\text { NS } \\
\text { NS }\end{array}$ \\
\hline
\end{tabular}

* Tissues from fed 19-day pregnant $(n=6)$ and age-matched vrigin $(n=8)$ rats were incubated 150 min in KRB. The table summarizes mean 土SEM values for FFA within tissue and for glycerol within medium at the end of incubation. (In the KRB systems, no FFA were released into the medium.) Mean ISEM values for net lipolysis and esterification were derived as per Vaughan (28).

$\ddagger P$ denotes significance of the effects of insulin on basal (KRB vs. KRB + insulin) or stimulated (KRB + epinephrine vs. $\mathrm{KRB}+$ epinephrine + insulin) lipolysis within each group of animals.

$\$ P$ denotes significance of the effects of pregnancy by comparing pregnant vs. virgin animals.

0.02) whereas net esterification did not differ in the two groups (Table III). During incubation in KRB-Alb + glucose, the removal of restraining amounts of FFA by esterification (31) enabled more lipolysis to occur in both groups (Table III). However, net lipolysis remained about $60 \%$ greater in the tissues from the gravid animals $(P<0.01)$ coincident with an equally greater net esterification $(P<0.01)$.

Thus, every aspect of fat turnover is augmented in adipose tissues from the fed pregnant animals, and heightened lipolysis rather than impaired esterification seems responsible for the enhanced efflux of FFA.

Responsiveness to insulin. The effects of insulin were examined to assess whether resistance to insulin action could be implicated in these phenomena.

As shown in Table III, addition of $50 \mu \mathrm{U} / \mathrm{ml}$ insulin to $\mathrm{KRB}-\mathrm{Alb}+$ glucose media dampened FFA and glycerol release from adipose tissue of pregnant as well as virgin animals. On a percentile basis, the reductions of net lipolysis by insulin (i.e. KRB-Alb + glucose vs. $\mathrm{KRB}-\mathrm{Alb}+$ glucose + insulin) were not different in the two groups: $37.7 \pm 8.7 \%$ in the pregnant and 41.1 $\pm 7.1 \%$ in the virgin.
Similar results were obtained during 150 -min incubations in simple KRB systems (Table IV). In the absence of either glucose to facilitate esterification, or albumin to permit efflux of tissue FFA, differences in basal lipolysis between tissues from pregnant and virgin animals could not be demonstrated (Table IV) presumably because the higher initial tissue FFA (Table I) inhibited full lipolysis (31) in the pregnant rats. However, addition of $50 \mu \mathrm{U} / \mathrm{ml}$ insulin obtunded basal as well as epinephrine-stimulated lipolysis to an equal degree in both groups (Table IV). Thus, isolated adipose tissue from fed pregnant rats did not display absolute or relative resistance to the antilipolytic effects of insulin under any experimental situation.

To evaluate tissue sensitivity to purely anabolic actions of insulin, formation of labeled fatty acids was examined. Table V summarizes results obtained during incubation of adipose tissue from fed animals for $60 \mathrm{~min}$ in $\mathrm{KRB}$ containing $5 \mathrm{~mm}$ glucose $-1-{ }^{14} \mathrm{C}$ or glucose- $6-{ }^{14} \mathrm{C}$. Net biosynthesis of fatty acids in vitro by segments of lumbar fat from pregnant and virgin rats was not significantly different in the absence of added insulin (" 0 insulin") nor in the presence of submaximal (100 $\mu \mathrm{U} /$ 
TABLE V

Effect of Pregnancy on the Formation of Fatty Acids from Labeled Glucose by Adipose Tissue In Vitro*

Tissue fatty acid-14 $\mathrm{C}$

mumoles of glucose carbon/mg tissue protein

\begin{tabular}{|c|c|c|c|c|c|c|}
\hline \multirow[t]{2}{*}{ Insulin, $\mu \mathrm{U} / \mathrm{ml} \ldots$} & \multicolumn{2}{|c|}{$\mathbf{0}$} & \multicolumn{2}{|c|}{100} & \multicolumn{2}{|c|}{1000} \\
\hline & Glucose-1-14C & Glucose-6-14C & Glucose-1-14C & Glucose-6-14C & Glucose-1-14C & Glucose-6-14C \\
\hline \multicolumn{7}{|l|}{ A. Fed Rats } \\
\hline $\begin{array}{l}\text { Pregnant (6) } \\
\text { Virgin (6) } \\
\quad P\end{array}$ & $\begin{array}{c}11.6 \pm 2.4 \\
13.2 \pm 2.9 \\
\mathrm{NS}\end{array}$ & $\begin{array}{c}18.2 \pm 3.9 \\
12.2 \pm 2.4 \\
\mathrm{NS}\end{array}$ & $\begin{array}{c}33.4 \pm 6.3 \\
21.6 \pm 4.0 \\
\mathrm{NS}\end{array}$ & $\begin{array}{c}68.1 \pm 18.1 \\
48.5 \pm 6.0 \\
\mathrm{NS}\end{array}$ & $\begin{array}{c}69.1 \pm 11.3 \\
42.6 \pm 7.8 \\
\mathrm{NS}\end{array}$ & $\begin{array}{c}212.0 \pm 61.8 \\
118.6 \pm 19.1 \\
\text { NS }\end{array}$ \\
\hline \multicolumn{7}{|l|}{ B. Fasted Rats } \\
\hline $\begin{array}{l}\text { Pregnant (5) } \\
\text { Virgin (6) } \\
\quad P\end{array}$ & $\begin{array}{c}0.20 \pm 0.05 \\
0.16 \pm 0.04 \\
\mathrm{NS}\end{array}$ & $\begin{array}{c}0.25 \pm 0.05 \\
0.13 \pm 0.04 \\
\mathrm{NS}\end{array}$ & $\begin{array}{c}0.50 \pm 0.20 \\
1.00 \pm 0.30 \\
N S\end{array}$ & $\begin{array}{c}1.60 \pm 1.00 \\
1.70 \pm 0.60 \\
N S\end{array}$ & $\begin{array}{c}7.10 \pm 5.50 \\
4.50 \pm 1.80 \\
N S\end{array}$ & $\begin{array}{c}14.5 \pm 11.0 \\
8.6 \pm 4.0 \\
\text { NS }\end{array}$ \\
\hline
\end{tabular}

* Tissues were incubated $60 \mathrm{~min}$ in $2 \mathrm{ml} \mathrm{KRB}$ containing $5 \mathrm{~mm}$ glucose-1-14 $\mathrm{C}$ or glucose-6-14 $\mathrm{C}$; and 0,100, or $1000 \mu \mathrm{U} / \mathrm{ml}$ insulin.

$\mathrm{ml})$ or maximal $(1000 \cdot \mu \mathrm{U} / \mathrm{ml})$ insulin stimulation (Table V).

With epididymal fat, the recovery of radioactivity in $\mathrm{CO}_{2}$, fatty acids, and glyceride-glycerol has accounted for $70-90 \%$ of glucose assimilation in vitro $(24,32)$. By this criterion, glucose "uptake" was about one-third greater in adipose tissue from pregnant than virgin rats even in the absence of added insulin (Tables II and V). If the relationships can be extrapolated to events in vivo, it would appear that the lower plasma glucose in the fed pregnant rat $(3-5,22)$ is not attended by glucose deprivation in adipose tissue; and that adipose tissue is not involved in the diminished hypoglycemic response to insulin (33). Thus, not only is responsiveness to insulin preserved, but metabolism is geared to compensate for the prevailing lower concentration of extracellular glucose.

\section{Adipose tissue from 48-hr fasted animals \\ RELATIONSHIPS IN Vivo}

Following a $48 \mathrm{hr}$ fast, plasma glucose falls to near hypoglycemic levels in the 19-day pregnant rat (3-5, 22) ; plasma insulin ceases to be greater than in nongravid animals $(4,5)$ and urinary catecholamine excretion is increased (6) (whereas urinary catecholamines are unaffected by pregnancy when food is available [6]). Coincident (and perhaps associated) with these changes, the hyperlipacidemia (elevated FFA levels) and ketonemia of starvation are markedly exaggerated in the pregnant rat $(3-5,22)$. Table I summarizes values for the adipose tissue content of FFA and glycerol under these circumstances. Although the $48 \mathrm{hr}$ fast increased tissue FFA and glycerol in nongravid as well as gravid animals, the increments for both were 2.7 -fold greater in the pregnant group. Thus, FFA were approximately doubled in the adipose tissue of fasted pregnant rats but increased only about $50 \%$ in the virgin (Table I).

The divergences in vivo prompted repeat studies in vitro. It was felt that prior fast should enhance the in vitro differences between tissues from fed pregnant and nonpregnant animals which we have ascribed to gestational activation of lipolysis (vide supra).

\section{Metabolism In Vitro}

The per cent of total radioactivity per milligram tissue protein which was recoverable as ${ }^{16} \mathrm{CO}_{2}$ or glycerideglycerol $-^{14} \mathrm{C}$ after $60 \mathrm{~min}$ incubation in $\mathrm{KRB}$ was diminished by fasting (Table II). However, the absolute differences in glucose oxidation and esterification between tissues from gravid and nongravid animals were, if anything, more pronounced.

During more prolonged incubation in KRB-Alb ( Table VI) both groups released greater amounts of FFA and glycerol into the medium than in the fed state ( $\mathrm{Ta}$ ble III). However, the disparities between pregnant and virgin animals were even more marked following $48 \mathrm{hr}$ fast (Table VI). Inclusion of glucose (i.e. KRB-Alb + glucose) effected proportionally smaller increases in net esterification after fasting (Table VI) than in the fed state (Table III) but caused even greater differences in net lipolysis between the virgin and pregnant rats (Table VI). Under such circumstances, addition of insulin $(50 \mu \mathrm{U} / \mathrm{ml})$ reduced net lipolysis $10.1 \pm 4.1 \%$ in pregnant $(P<0.05)$ and $31.4 \pm 1.4 \%$ in virgin $(P<$ 0.001 ) (Table VI) - a significant difference between the two groups $(P<0.01)$.

Fasting also did not alter the relative responsiveness to the effects of insulin upon glucose disposition. As shown in Table $\mathrm{V}$, the decreased formation of fatty acids after $48 \mathrm{hr}$ fast was minimally but equally in- 
TABLE VI

Effect of Pregnancy on Lipolysis and Esterification by Adipose Tissue during Incubation in Albumin-Containing Media: Fasted Rats*

\begin{tabular}{|c|c|c|c|c|c|}
\hline & KRB-Alb & $\begin{array}{l}\text { KRB-Alb } \\
+ \text { glucose }\end{array}$ & $P$ & $\begin{array}{c}\text { KRB-Alb + glucose } \\
+ \text { insulin }\end{array}$ & $P$ \\
\hline $\begin{array}{l}\text { Final mediun } \\
\text { glycerol }\end{array}$ & & /mg tissue protein & & 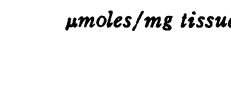 & tein \\
\hline $\begin{array}{l}\text { Pregnant } \\
\text { Virgin } \\
\quad P\end{array}$ & $\begin{array}{c}0.286 \pm 0.026 \\
0.148 \pm 0.013 \\
<0.01\end{array}$ & $\begin{array}{c}0.350 \pm 0.011 \\
0.179 \pm 0.020 \\
<0.001\end{array}$ & $\begin{array}{l}<0.01 \\
<0.02\end{array}$ & $\begin{array}{c}0.315 \pm 0.008 \\
0.128 \pm 0.013 \\
\quad<0.001\end{array}$ & $\begin{array}{l}<0.05 \\
<0.001\end{array}$ \\
\hline \multicolumn{6}{|c|}{ Final medium FFA } \\
\hline $\begin{array}{l}\text { Pregnant } \\
\text { Virgin } \\
\quad P\end{array}$ & $\begin{array}{c}0.444 \pm 0.058 \\
0.223 \pm 0.020 \\
<0.01\end{array}$ & $\begin{array}{c}0.568 \pm 0.030 \\
0.226 \pm 0.041 \\
<0.001\end{array}$ & $\begin{array}{l}\text { NS } \\
\text { NS }\end{array}$ & $\begin{array}{c}0.364 \pm 0.062 \\
0.054 \pm 0.032 \\
<0.01\end{array}$ & $\begin{array}{l}<0.05 \\
<0.02\end{array}$ \\
\hline \multicolumn{6}{|c|}{ Final tissue FFA } \\
\hline $\begin{array}{l}\text { Pregnant } \\
\text { Virgin } \\
P\end{array}$ & $\begin{aligned} & 0.527 \pm 0.088 \\
& 0.147 \pm 0.010 \\
&<0.01\end{aligned}$ & $\begin{array}{c}0.361 \pm 0.028 \\
0.153 \pm 0.017 \\
<0.001\end{array}$ & $\begin{array}{c}<0.05 \\
\text { NS }\end{array}$ & $\begin{array}{c}0.338 \pm 0.019 \\
0.132 \pm 0.025 \\
<0.001\end{array}$ & $\begin{array}{l}\text { NS } \\
\text { NS }\end{array}$ \\
\hline \multicolumn{6}{|l|}{ Net lipolysis } \\
\hline $\begin{array}{l}\text { Pregnant } \\
\text { Virgin } \\
\quad P\end{array}$ & $\begin{array}{c}0.790 \pm 0.082 \\
0.420 \pm 0.040 \\
<0.01\end{array}$ & $\begin{array}{c}0.987 \pm 0.031 \\
0.529 \pm 0.060 \\
<0.001\end{array}$ & $\begin{array}{l}<0.02 \\
<0.01\end{array}$ & $\begin{array}{c}0.883 \pm 0.029 \\
0.366 \pm 0.042 \\
<0.001\end{array}$ & $\begin{array}{l}<0.05 \\
<0.001\end{array}$ \\
\hline \multicolumn{6}{|c|}{ Net esterification } \\
\hline $\begin{array}{l}\text { Pregnant } \\
\text { Virgin } \\
P\end{array}$ & $\begin{array}{c}0.445 \pm 0.123 \\
0.259 \pm 0.026 \\
\text { NS }\end{array}$ & $\begin{array}{c}0.684 \pm 0.029 \\
0.358 \pm 0.037 \\
<0.001\end{array}$ & $\begin{array}{l}<0.01 \\
<0.001\end{array}$ & $\begin{array}{c}0.808 \pm 0.065 \\
0.387 \pm 0.037 \\
\quad<0.001\end{array}$ & $\begin{array}{c}<0.05 \\
\text { NS }\end{array}$ \\
\hline
\end{tabular}

* Tissues from fasted 19-day pregnant $(n=5)$ and age-matched virgin $(n=6)$ rats were incubated 150 min in KRB-Alb. Experimental conditions, presentation of data, and statistical analyses are as in Table III.

creased by insulin in tissues from pregnant as well as virgin animals.

\section{DISCUSSION}

Heightened availability of FFA within adipose tissue of the fed 19-day pregnant rat has been documented in the present studies. It has been shown that this coincides with an augmented cleavage of stored triglycerides during incubation in vitro as evidenced by greater net production of FFA and glycerol and altered metabolism of labeled glucose. The enhanced lipolysis was independent of glucose availability, occurring in the absence as well as the presence of glucose. No impairment in the anabolic actions of insulin was discerned as judged by the effects upon the formation of fatty acids from labeled glucose. The antilipolytic effectiveness of insulin was likewise maintained and could not be implicated. In the presence of glucose and albumin, esterification as well as lipolysis was greater in adipose tissue from pregnant than nongravid rats indicating increased turnover of tissue lipids analogous to that observed after incubating epididymal fat with a variety of lipolytic agents (30). In other words, isolated fat from the fed 19-day pregnant rat seems to behave as if subjected to a primary stimulation of lipolysis rather than an impairment of esterification or resistance to insulin.

In the light of these findings, the increase in glucose uptake and net gas exchange produced by insulin in adipose tissue from fed 18- to 20-day pregnant rats $(34,35)$ more likely results from the greater esterification and glucose oxidation than heightened sensitivity to insulin. Likewise, the greater total labeling of maternal fat after intravenous glucose- ${ }^{16} \mathrm{C}$ (36) may represent an increment in glyceride-glycerol rather than fatty acid synthesis. Indeed, Fain and Scow found that the incorporation of tritiated water into maternal fatty acids in the 20-day fed pregnant rat was indistinguishable from that of virgin control animals although fatty acid synthesis was substantially greater in the 16-day pregnant animal (22).

Whether the intrinsic activation of lipolysis in adipose tissue fully accounts for the observed elevation of 
plasma FFA in the fed pregnant rat cannot be answered. Other factors such as the greater total body fat (22), the lower plasma glucose $(3-5,22)$, the lower plasma albumin (37), and the heightened cardiac output (38), with possibly augmented perfusion of adipose tissue could also be contributory in vivo. Some of the FFA might even originate from the hypertriglyceridemia of dietary origin (3).

The precise reasons for the activation of lipolysis in adipose tissue in the fed state are also unclear. We have demonstrated that the disparities in lipolysis between lumbar fat from gravid and nongravid animals are accentuated by fasting. Indeed, after $48 \mathrm{hr}$ fast in pregnancy, some added resistance to insulin may even be manifest as evidenced by diminished responsiveness to the antilipolytic actions of the hormone in vitro. Thus, the possibility that some adaptations to the "exaggerated" starvation of pregnancy $(1,4,5)$ are carried over into the fed state cannot be excluded. However, it does not seem likely that this is of major importance since $24 \mathrm{hr}$ catecholamine excretion is not different in pregnant that in nonpregnant animals during ad lib. feeding (6), and it is our impression that pregnant rats not only eat more (3) but also more frequently and throughout the day in late gestation. ${ }^{5}$ It seems more likely that the sustained activation of lypolysis is triggered by something that acts continuously. The hormones of pregnancy could qualify for such a role since they are released from placenta and ovary without dietary feedback regulation and in accord with the growth and development of the conceptus $(39,40)$. One such hormone, placental lactogen, has displayed lipolytic properties in vitro (27) although the role of placental lactogen is less clear in the rat than in primates (see reference 5 for review of literature).

During the normal course of pregnancy, where the mother has unlimited access to food, the lipolytic activation need little effect the tendency to increase adipose tissue mass. Our data would suggest that any putative restraint to fatty acid synthesis is apparently overcome by the increase in plasma insulin. In addition, during conjoint availability of glucose and insulin, most of the fatty acids liberated by lipolysis are recovered by the concurrent increase in esterification. The cost to the tissue may be measured in terms of a small net FFA loss plus the energy required for esterification (41), the deficit in fatty acids apparently being more than compensated by lipid of dietary or hepatic origin.

If lipolytic activation appears established at limited cost to the animal, what useful purpose might it serve? A reasonable hypothesis would envision the increase in lipid stores, and the coexistent increase in fat turnover

\footnotetext{
${ }^{5}$ Knopp, R. H., E. Herrera, and N. Freinkel. Unpublished observations.
}

as "insurance" against possible food deprivation, particularly in late gestation when the fetal drains on maternal glucose and amino acids are greatest. Should fasting supervene, the pregnant animal is ideally poised to mobilize and utilize lipids at an accelerated rate, and thereby to spare nonlipid nutrients for fetal growth and for maternal tissues which will not accept other fuels.

\section{ACKNOWLEDGMENTS}

We are indebted to Mrs. Susan Tuckett, Miss Jayne Martin, and Miss Dorothy Turek for excellent technical assistance.

This work was supported in part by Research Grant AM-10699 and Training Grant AM-05071 from the National Institute of Arthritis and Metabolic Diseases, U. S Public Health Service, Bethesda, Md.

\section{REFERENCES}

1. Freinkel, N. 1969. Homeostatic factors in fetal carbohydrate metabolism. In Fetal Homeostasis. Vol 4. R. M. Wynn, editor. Appleton-Century-Crofts Inc., New York. 85.

2. McKay, D. G., and H. Kaunitz. 1963. Studies of the generalized Schwartzman reaction induced by diet. VI. Effects of pregnancy on lipid composition of serum and tissues. Metabolism. 12: 990.

3. Scow, R. O., S. S. Chernick, and M. S. Brinley. 1964. Hyperlipemia and ketosis in the pregnant rat. Amer. $J$. Physiol. 206: 796.

4. Freinkel, N., E. Herrera, R. H. Knopp, and H. J. Ruder. 1969. Metabolic realignments in late pregnancy: a clue to diabetogenesis? In Early Diabetes. R. A. Camerini-Davalos, editor. Academic Press Inc., New York. 205.

5. Herrera, E., R. H. Knopp, and N. Freinkel. 1969. Carbohydrate metabolism in pregnancy. VI. Plasma fuels, insulin, liver composition, gluconeogenesis, and nitrogen metabolism during late gestation in the fed and fasted rat. J. Clin. Invest. 48: 2260.

6. Herrera, E., R. H. Knopp, and N. Freinkel. 1969. Urinary excretion of epinephrine and norepinephrine during fasting in late pregnancy in the rat. Endocrinology. 84: 447.

7. Ball, E. G., D. B. Martin, and O. Cooper. 1959. Studies on the metabolism of adipose tissue. I. The effect of insulin on glucose utilization as measured by the manometric determination of carbon dioxide output. J. Biol. Chem. 234 : 774.

8. Chen, R. F. 1967. Removal of fatty acids from serum albumin by charcoal treatment. J. Biol. Chem. 242: 173.

9. Hagen, J. H., and E. G. Ball. 1960. Studies on the metabolism of adipose tissue. IV. The effect of insulin and adrenaline on glucose utilization, lactate production, and net gas exchange. J. Biol. Chem. 235: 1545.

10. Freinkel, N. 1961. Extrathyroidal actions of pituitary thyrotropin: effects on the carbohydrate, lipid and respiratory metabolism of rat adipose tissue. J. Clin. Invest. 40: 476.

11. Freinkel, N., A. K. Cohen, R. A. Arky, and A. E. Foster. 1965. Alcohol hypoglycemia. II. A postulated mechanism of action based on experiments with rat liver slices. J. Clin. Endocrinol. 25: 76.

12. Folch, J., M. Lees, and G. H. Sloane Stanley. 1957. A simple method for the isolation and purification of total lipides from animal tissues. J. Biol. Chem. 226: 497. 
13. Vaughan, M. 1961. Effect of hormones on glucose metabolism in adipose tissue. J. Biol. Chem. 236: 2196.

14. Garland, P. B., and P. J. Randle. 1962. A rapid enzymatic assay for glycerol. Nature (London). 196: 987.

15. Dole, V. P., and H. Meinertz. 1960. Microdetermination of long-chain fatty acids in plasma and tissues. J. Biol. Chem. 235: 2595.

16. Duncombe, W. G. 1964. The colorimetric micro-determination of non-esterified fatty acids in plasma. Clin. Chim. Acta. 9: 122.

17. Lowry, O. H., N. J. Rosebrough, A. L. Farr, and R. J. Randall. 1951. Protein measurement with the Folin phenol reagent. J. Biol. Chem. 193: 265.

18. Schmidt, G., and S. J. Thannhauser. 1945. A method for the determination of deoxyribonucleic acid, ribonucleic acid, and phosphoproteins in animal tissues. J. Biol. Chem. 161: 83.

19. Winegrad, A. I., and A. E. Renold. 1958. Studies on rat adipose tissue in vitro. I. Effects of insulin on the metabolism of glucose, pyruvate, and acetate. J. Biol. Chem. 233: 267.

20. Ballard, F. J., and R. W. Hanson. 1969. Measurements of adipose-tissue metabolites in vivo. Biochem. J. 112: 195.

21. Freinkel, N. 1960. Further observations concerning the action of pituitary thyrotropin on the intermediate metabolism of sheep thyroid tissue in vitro. Endocrinology. 66: 851 .

22. Fain, J. N., and R. O. Scow. 1966. Fatty acid synthesis in vivo in maternal and fetal tissues in the rat. Amer. J. Physiol. 210: 19.

23. Cahill, G. F., Jr., B. Leboeuf, and R. B. Flinn. 1960. Studies on rat adipose tissue in vitro. VI. Effect of epinephrine on glucose metabolism. J. Biol. Chem. 235: 1246.

24. Lynn, W. S., R. M. MacLeod, and R. H. Brown. 1960. Effects of epinephrine, insulin, and corticotrophin on the metabolism of rat adipose tissue. J. Biol. Chem. 235: 1904.

25. Leboeuf, B., and G. F. Cahill, Jr. 1961. Studies on rat adipose tissue in vitro. VIII. Effect of preparations of pituitary adrenocorticotropic and growth hormones on glucose metabolism. J. Biol. Chem. 236: 41.

26. Katz, J., B. R. Landau, and G. E. Bartsch. 1966. The pentose cycle, triose phosphate isomerization, and lipogenesis in rat adipose tissue. J. Biol. Chem. 241: 727.

27. Turtle, J. R., and D. M. Kipnis. 1967. The lipolytic action of human placental lactogen on isolated fat cells. Biochim. Biophys. Acta. 144: 583.
28. Vaughan, M. 1962. The production and release of glycerol by adipose tissue incubated in vitro. J. Biol. Chem. 237: 3354

29. Robinson, J., and E. A. Newsholme. 1967. Glycerol kinase activities in rat heart and adipose tissue. Biochem. J. 104: 2 c.

30. Vaughan, M., and D. Steinberg. 1963. Effect of hormones on lipolysis and esterification of free fatty acids during incubation of adipose tissue in vitro. J. Lipid Res. 4: 193 .

31. Rodbell, M. 1965. Modulation of lipolysis in adipose tissue by fatty acid concentration in fat cell. $A n n . N . Y$. Acad. Sci. 131: 302

32. Flatt, J. P., and E. G. Ball. 1964. Studies on the metabolism of adipose tissue. XV. An evaluation of the major pathways of glucose catabolism as influenced by insulin and epinephrine. J. Biol. Chem. 239: 675.

33. Knopp, R. H., H. J. Ruder, E. Herrera, and N. Freinkel. Carbohydrate metabolism in pregnancy. VII. Insulin tolerance during late pregnancy in the fed and fasted rat. Acta Endocrinol. In press.

34. Leake, N. H., and R. L. Burt. 1966. Response of rat adipose tissue to insulin during pregnancy. Amer. J. Obstet. Gynecol. 96: 131.

35. Leake, N. H., and R. L. Burt. 1969. Effect of HPL and pregnancy on glucose uptake in rat adipose tissue. Amer. J. Obstet. Gynecol. 103: 39.

36. Clark, C. M., Jr., G. F. Cahill, Jr., and J. S. Soeldner 1968. Effects of exogenous insulin on the rate of fatty acid synthesis and glucose $\mathrm{C}^{14}$ utilization in the twentyday rat fetus. Diabetes. $17: 362$.

37. Hytten, F. E., and I. Leitch. 1964. The Physiology of Human Pregnancy. Blackwell Scientific Publications Ltd., Oxford. 42.

38. Hytten, F. E., and I. Leitch. 1964. The Physiology of Human Pregnancy. Blackwell Scientific Publications Ltd., Oxford. 50.

39. Grieg, M., M. G. Coyle, W. Cooper, and J. Walker. 1962. Plasma progesterone in mother and foetus in the second half of human pregnancy. J. Obstet. Gynaecol. Brit. Commun. 69: 772 .

40. Samaan, N., S. C. C. Yen, H. Friesen, and O. H. Pearson. 1966. Serum placental lactogen levels during pregnancy and in trophoblastic disease. J. Clin. Endocrinol. 26: 1303.

41. Ball, E. G., and R. L. Jungas. 1961. On the action of hormones which accelerate the rate of oxygen consumption and fatty acid release in rat adipose tissue in vitro. Proc. Nat. Acad. Sci. U. S. A. 47: 932. 